\title{
SPORTS IN SCHOOLS IN THE PROVINCE OF VOLHYNIA IN THE YEARS 1921-1939
}

\author{
Teresa Drozdek-Małolepsza, A, B, C, D, E Eligiusz Małolepszy A, B, C, D, E \\ Uniwersytet Humanistyczno-Przyrodniczy im. Jana Długosza w Częstochowie

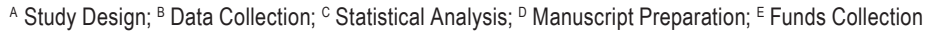 \\ Address for correspondence: \\ Teresa Drozdek-Małolepsza \\ Uniwersytet Humanistyczno-Przyrodniczy im. Jana Długosza w Częstochowie \\ Jerzego Waszyngtona 4/8, 42-200 Częstochowa, Poland \\ E-mail: t.drozdek-malolepsza@ujd.edu.pl
}

\begin{abstract}
Ahstract The aim of this paper was presentation of sports in schools in the province of Volhynia in the years 1929-1939. Schools in Volhynia were diversified in terms of nationality. Apart from Polish schools, with Polish as a language of instruction and a subject, there were Polish schools with languages of national minorities inhabiting the Volhynia province, as well as Ukrainian, Czech, German, Russian, Yiddish, Hebrew, Yiddish-Hebrew and Utraquist schools.

In the years 1929-1939, there was rapid development of sports in schools in the province of Volhynia. This process was particularly visible in the second half of the 1920s and in the 1930s. School sport was particularly popular in secondary schools. Among sports, school children and adolescents practiced mainly athletics, sport games, shooting, water sports and winter sports. School Sports Circles and Clubs were organised. Sport competition was developed mainly at the local, district and provincial levels. In the 1930s, the representation of Volhynian (Lutsk) school district participated in national sports competitions. School sports contests between Kremenets Lyceum and "The Sułkowskis" Junior High School in Rydzyn, taking place in the years 1933-1938, were regarded as blue-ribbon school contests.

Apart from Kremenets, Dubno, Kovel, Luck and Równe were also regarded to be strong school sports centres in Volhynia.
\end{abstract}

Key WOrds school sports, province of Volhynia, Kremenets Lyceum, sports competition

\section{Introduction}

The purpose of the paper is to present sports in schools in the province of Volhynia in the years 1921-1939. The national diversity of the inhabitants of the province of Volhynia force the adjustment of the system of education to such a situation. Apart from Polish schools, with Polish as a language of instruction and a subject, there were Polish schools with languages of national minorities inhabiting the Volhynia province, as well as Ukrainian, Czech, German, Russian, Yiddish, Hebrew, Yiddish-Hebrew and Utraquist schools (Archiwum Akt Nowych w Warszawie AAN, Urząd Wojewódzki Wołyński - UWW, File Ref. 979/83, Report on the situation in Volhynia in September 1933 and 1934 together with the work plan for the Province of Volhynia, p. 43). 
Utraquist schools were introduced by the government act in 1924. They constituted the basic type of state school, whose message was "raising children of Polish and non-Polish nationality as good citizens" in mutual respect for their national identity (the Act of July 31, 1924, containing certain provisions on the organisation of schools; Journal of Laws 1924, №. 79, item 776, pp. 1212-1213).

In September 1934, there were 1,931 school facilities in the province of Volhynia, of which the vast majority - 1,745 - were state schools (AAN, UWW, Ref. No. 979/83, Report on the situation in Volhynia in September 1933 and 1934 together with the work plan of the province of Volhynia, p. 43). In the educational structure, majority of schools were public elementary schools $(1,732)$ and private elementary schools (149). Majority of the teachers employed in those schools there were Poles (2,817), Ukrainians (472), Russians (100), Czechs (36) and Jews (23). In the school year 1933/1934, 362,108 children remained in school duty in the province of Volhynia, while 236,516 children attended schools (AAN, UWW, Ref. No. 979/83, Report on the situation in Volhynia in September 1933 and 1934 with a work plan for the province of Volhynia, p. 43; Kęsik, 2008). In 1938, 73.3\% of pupils fulfilled their compulsory school attendance, and the number of elementary school pupils increased to 300,000 . The effort to promote education was reflected in the decline in illiteracy. In the mid-1920s over $68 \%$ of the Volhynia population could not read and write, whereas in 1931 the percentage of illiterates fell to $47.8 \%$. Against the background of the whole country, where this percentage was $23 \%$ at that time, it can be stated that it was a very backward area (Kęsik, 2008). The greatest cognitive significance on the subject is assigned to the works of Eligiusz Małolepszy, Teresa Drozdek-Małolepsza and Daniel Bakota (Małolepszy, Drozdek-Małolepsza, Bakota, 2017; Małolepszy, DrozdekMałolepsza, 2019).

\section{Sports competitions in schools at the local and provincial level}

The first Interschool Sports Competition of general secondary schools was organised on May 23-24, 1925 in Rivne (Wychowanie Fizyczne, 1925, No. 3-4, p. 268). The competition took place on the sports field of the „Sokół” Gymnastic Society (TS). There were 18 male and 12 female teams registered for the competition. A total of 320 competitors participated in the event. The idea was to show the physical fitness of young people. The programme of the competition included team games as part of combined track and field events. A challenge award was prepared only for contestants competing in pentathlon (boys) and track and field triathlon (girls). The first place and the challenge award among boys were won by pupils of the gymnasium in Rivne. Among female teams, the first place and the trophy were won by female contestants from the gymnasium in Zdolbuniv. The competition programme also included track and field tetrathlon for boys for two age groups - from 12 to 15 years old and from 15 to 18 years old. The team from Kovel won in the younger age group, and in the older age group the team from Volodymyr-Volynskyi won the contest. There was also tetrathlon for girls between 12 and 15 years old. Out of 5 competing teams the first place was won by the girls from Lutsk. As part of the sports festival, school teams of Przysposobienie Wojskowe (PW) competed. 10 teams took part in the shooting competitions, and 12 players competed in bayonet fencing. Shooting competition took place over a distance of $100 \mathrm{~m}$ to a target with 10 rings without backrest. The team of the Teacher Training Seminary from Lutsk won the competition. In bayonet fencing the students of the School of Commerce in Rivne - Generowicz and Wiśniewski - turned out to be the best. Three teams took part in the competition of the PW school corps. The Cadet Corps of the "Juliusz Słowacki" State Junior High School in Kovel distinguished themselves in the PW competition (Księga pamiątkowa..., 1926, p. 21). 
The successive competition (inter-school) took place on June 18-20, 1926 in Lutsk. Primary school students were invited to participate. In order to popularise and increase the interest of the local community in physical activity, the authorities of the Volhynia District Board of Education planned to hold county competitions for schools functioning in the district before starting the district competitions. The programme of the competitions was the same during both district and county rivalry (Dziennik Urzędowy Kuratorium Okręgu Szkolnego Wołyńskiego, 1925, pp. 226-227). The purpose of organising the School Youth Day in Volhynia was to demonstrate physical fitness and military training. The programme of the competition, due to introduction of multi-combat events, took into account the collective effort of individual teams. Commune and district competitions were organised for pupils of rural elementary schools aged 10 to 15. District competitions were organised in all 10 districts of the province of Volhynia (Wychowanie Fizyczne, 1926, p. 255). The competition of elementary school teams was conducted in two groups. The contestants were divided according to their age: girls - 10-14 years old, boys $-13-15$ years old. The competition of one of the groups concerned only their participation in the tetrathlon (Dziennik Urzędowy Kuratorium Okręgu Szkolnego Wołyńskiego, 1926, No. 7, pp. 188-189). The team was to consist of 20 people - 8 boys and 12 girls. The district could be represented by the maximum of two teams, assuming it would be one female team and one male team. The boys competed in tetrathlon, military pentathlon and track-and-field pentathlon. The team consisted of 20 participants, 8 in the first two competitions and 4 in the track-and-field pentathlon. The competitors were allowed to participate only in one group. The terms of the regulations had an impact on the participation in the competition of a wide group of young people, because a representation of a district could consist, in the group discussed above, of max. 40 contestants.

High school teams were reported for the entire programme. Everyone had to participate in free exercises. The competition programme included a cycling relay in which a team of 10 contestants had the right to take part; basketball games the final of which was to be played during county competitions, with the participation of two male and two female teams selected in qualification contests (Dziennik Urzędowy Kuratorium Okręgu Szkolnego Wołyńskiego, 1926, No. 4, p. 114). The transfer trophy in female contests was won by the pupils from the State Junior School in Kovel. Due to weather conditions, the track-and-field pentathlon for boys had to be cancelled (Wychowanie Fizyczne, 1926, No. 4, p. 256). The challenge award for boy teams remained in the possession of the State Junior High School in Rivne - the winner of the 1925 competition. A total of 474 students - 212 girls and 262 boys participated in the competition (Nowak, 1996). The District Sports Day of School Youth took place in 1927 on May 27-28, in Rivne. Apart from state schools, pupils from private schools participated in the competition, including Russian Private Junior High School. The number of participants from private schools was insignificant, because not all institutions had physical exercise classes (Wychowanie Fizyczne, 1927, No. 7-8, pp. 211). In total, the competition was attended by 471 competitors -293 boys and 178 girls. The competition in combined track-andfield events was carried out in two groups of pupils - younger and older (over 15 years of age). Each team consisted of 4 players. The competitions for younger boys included team tetrathlon: high jump, long jump, $60 \mathrm{~m}$ run and smallcalibre weapon shooting at the distance of $50 \mathrm{~m}$. The older boys competed in the team pentathlon (long jump, pole vault, javelin throw, shot put and $4 \times 100 \mathrm{~m}$ relay). Competitions for girls were held as part of a team track-and field triathlon: high jump, $60 \mathrm{~m}$ run, balance beam exercises. Older girls competed in long jump, archery and $4 \times 60 \mathrm{~m}$ relay race. In the tetrathlon for younger boys, the State Junior High School in Rivne, before the Junior High Schools in Dubno and Lutsk, turned out to be the best. The track-and-field competition for older boys was won by the team 
of the State Junior High School in Lutsk ahead of the team of the Junior High School in Rivne. Third place was taken by pupils of the Junior High School in Ostroh. The competition in triathlon, among 11 teams of younger girls, was won by the State Junior High School in Kovel, the second place went to the Junior High School in Dubno, and the third - to the Junior High School in Rivne. Among the older girls (12 teams), the team from Kovel proved to be the best. The second place went to the team from the Junior High School in Rivne, the third place went to the Junior High School in Lutsk. The School Youth Sports Festival programme has been extended to include toxophily as an individual competition.

There were also other competitions held, such as cross-country race over a distance of 2,000 m, and a $5 \times 1,000 \mathrm{~m}$ cycling relay race. The best team in the cross-country race was the High School in Kremenets (Wychowanie Fizyczne, 1927, No. 9-10, pp. 257). Team games included a basketball tournament in which 6 female and 10 male teams participated. The female group was won by the team from the Teacher Training Seminary from Ostroh; the male group tournament was won by the team of the State Junior High School in Rivne. The Challenge Award of the Board of Education for the best male team was won by the State Junior High School in Lutsk. The female team of the Junior High School in Kovel won the Challenge Award of the Board of Education of the Volhynia School District for the best female team once again (Wychowanie Fizyczne, 1927, No. 7-8, p. 212).

On the initiative of the Students' Sports Circle of the Kremenets Lyceum track-and-field competitions (track-and-field triathlon for girls, track-and-field triathlon for boys), and a tournament of sports games (Wołyń, 1933, No. 24, p. 10) were held. Inter-school competitions in track-and-field events were organised in Kremenets. The competition, held on May 5, 1932, included a 100 m run, shot put and high jump (Życie Krzemienieckie, 1932, No. 5, pp. 28-29). The competition was attended by teams from the K.L. Junior High School, K.L. Seminary, Local Government Junior High School as well as athletes from the $12^{\text {th }}$ Podolian Cavalry Regiment, who participated out of competition. In high jump, the best result was achieved by Krasuski $(157 \mathrm{~cm})$, whereas Ivanov achieved the best result in shot put $(13.30 \mathrm{~m})$.

In 1935, in the primary school in Mlyniv (Dubno district), there were 3 kayak sections with 9 kayaks that were built by students in the school workshop as part of handicraft classes. The students were also making skis and toboggans. The initiator of the production of sports equipment by the pupils was the headmaster of the school Edward Nowak, Eng. About 140 pupils participated in canoeing lessons combined with swimming lessons. The location of the village on the Ikva River was conducive to the implementation of these activities (Wołyń, 1935, No. 27, p. 9).

Pupils participated in competitions organised on the occasion of putting sports facilities into use. On July 21,1935 , after a ceremonial opening of the rowing harbour and swimming area on the Ikva River in Dubno, pupils competed in canoeing and swimming competitions (Wołyń, 1935, No. 31, p. 9). On September 22, 1935, the junior high school crew took the third place in the canoe competition organised in Dubno by the kayaking section of the Maritime and Colonial League (Wołyń, 1935, No. 40, p. 8). In the rowing regatta held in Dubno on September 29, 1935, in the competition of two paddlers and the helmsman, the crew of the local State Junior High School won the first place. The main prize was a challenge cup funded by the Dubno Rowing Association (Wołyń, 1935, No. 42, p. 8).

School sport was also carried out in other institutions of secondary education in the province of Volhynia. In 1933, the Sports Club of the State Measuring and Road School in Kovel organised a cross-country skiing race at a distance of $8 \mathrm{~km}$ (Wołyń, 1933, No. 10, p. 7). The winner was Lubiak, the second place went to Lipnicki.

On February 23, 1933, the Committee on Physical Education at the Central Pedagogical Library in Rivne organised the 1st Interschool Team Skating Competition for the Schools of Rivne (Wołyń, 1933, No. 12, p. 6). 
The competition program consisted of four skating competitions: races over a distance of $100 \mathrm{~m}$ and $200 \mathrm{~m}$ for girls, and races over a distance of $200 \mathrm{~m}$ and $400 \mathrm{~m}$ for boys. The competition gathered 130 participants and 1,500 spectators. Each team consisted of 4 people, competing individually. In the girls' skating race over a distance of $100 \mathrm{~m}$, the first two places were taken by pupils of the State Junior High School, the third place was taken by pupils of the H. Sienkiewicz Primary School; in girls' skating race over a distance of $200 \mathrm{~m}$ the best were again the pupils of the State Junior High School. In boys' competitions in the skating race over a distance of $200 \mathrm{~m}$ the first place was taken by the pupils of the $\mathrm{H}$. Sienkiewicz Primary School, while two next places were taken by representatives of the State Junior High School; the $400 \mathrm{~m}$ race was won by representatives of the Russian Junior High School, before the team from the Polish School of Economics (Polska Macierz Szkolna - PMS) and the State Junior High School.

As part of the winter sports action (1933/1934) in Kremenets, carried out by the Junior High School of the District Department, in cooperation with the School of Economics and Kremenets City Council, three sections were separated: skiing, tobogganing and skating (Życie Krzemienieckie, 1934, No. 2, pp. 53-54). The result of the campaign was, among others, the completion of a ski course for group leaders by two pupils. Under the guidance of physical education teachers, A. Hoffmanówna and H. Kobyliński, the Sports Club organised three ski courses. 28 boys, 16 girls and 10 students of the School of Economics participated in the courses. At the end of the courses competitions and ski trips were organised. Among the participants of the course for boys, 16 of them obtained the titles of group leaders.

On the initiative of the Municipal Committee of Physical Education and Military Training (MKWFiPW) in Lutsk, the Physical Education and Military Training Festival (WF and PW) has been organised annually to promote and develop physical activity in Lutsk and in the Lutsk district. In 1930 the Festival in Lutsk was held on June 7-9. The sports programme included sports competitions and shows of schoolchildren and a competition of clubs and sports associations. Pupils were to compete in sports games (palant - a Polish game similar to baseball, volleyball), in athletics and in shooting. Gymnastic shows were to be carried out by school students and the "Sokół" Gymnastic Society (TG) (Małolepszy et al., 2017).

Young people from schools in Kremenets performed very well during the Festival of Physical Education and Military Training on June 3, 1934, carried out on the sports field of the District Committee of Physical Education and Military Training (Życie Krzemienieckie, 1934, No. 6, pp. 269-270). The event was organised on the initiative of the Subject Committee on Physical Education, supervised by a school inspector, Bronisław Robak. Over 1,300 students took part in shows and competitions in physical education and sports, they represented: Kremenets Lyceum, primary schools, Orthodox Theological Seminary, Local Government Junior High and the School of Economics. The programme included: a gymnastic show, a demonstration lesson of physical education, relay runs, games and activities, sports games and a dance show.

The pupils obtained very good results during the Festival of Physical Education and Military Training held in Kovel on June 11, 1933 (Wołyń, 1933, No. 25, p. 9.). In the competition of games and fun, the winners were: in the volleyball competition of primary school girls - Primary School No. 1 in Kovel; in the volleyball in the competition of primary school boys - Primary School No. 3 in Kovel; in dodgeball - Primary School No. 4 in Kovel; women's volleyball, basketball, shooting and pentathlon - Junior High School Sports Club. A large number of competitions and disciplines carried out for school children deserves attention in the Kovel competition programme. 
The sport competition of high school students in Volhynia should be considered interesting. On October 13, 1935, there was a match held in Kremenets between the students of the Kremenets Lyceum and the State Junior High School in Dubno (Życie Krzemienieckie, 1935, No. 10, p. 454; Wołyń, 1935, No. 44, p. 10). The students competed in sports games, track-and-field events and shooting. The competition was social in nature and aimed at comparing the physical fitness of the two educational institutions. Each team consisted of 15 players. Sports games and track-and-field competitions were dominated by students from Kremenets, among others they won girls' and boys' volleyball events, boys' basketball and hazena (Czech handball), as well as in track-and-field triathlon. In small-calibre shooting students from Dubno proved to be better.

Another competition with the participation of young people from schools in Volhynia took place in Kremenets on May 22-23, 1937 (Życie Krzemienieckie, 1937, No. 10-11, pp. 231-233). There were representations of the State Junior High School from Ostroh, the Local Government Junior High School from Kremenets, Pedagogium and the Junior High School of Kremenets Lyceum which participated in the competition of girls (each team consisted of 10 girls). Eight teams from schools from Białokrynica, Kremenets, Dubno, Ostroh and Smyga entered the boys' competition. The competitions included athletics, sports games (hazena, basketball, volleyball), shooting (shooting with small-caliber weapons). The students from the Junior High School and Pedagogium of Kremenets Lyceum and the Junior High School in Dubno and Ostroh distinguished themselves in the competition.

Activities in the field of school sport were undertaken by the Polish Association of Physical Educators (PZWF) and the Interschool Commission of Physical Education (WF) in Lutsk. In the 1937/1938 reporting period, on the initiative of the above institutions, inter-school athletics competitions for high school youth were conducted three times and they were attended by over 70 students; inter-school gymnastics competitions were conducted three times with c. 60 students; ice hockey competitions were held twice; high school inter-school competitions in sports games in which 6 volleyball teams and 6 basketball teams took part were carried out four times; in consultation with the Regional PE Centre two swimming competition, with the participation of about 25 students, were held for a swimming badge, (Wołyń, 1938, No. 49, p. 5). In agreement with the Municipal Committee of Physical Education and Military Training (MKWF i PW) in Lutsk, the Interschool Festival of Physical Education and Military Training (WF i PW) was organised, attended by about 1,500 pupils from primary and secondary schools. The activity of the Polish Association of Physical Educators (PZWF) club in Lutsk should be assessed as extremely dynamic.

The Interschool Sports Youth Club in Kremenets Lyceum was the organiser of school sports competitions on September 25-26, 1937 (Małolepszy, Drozdek-Małolepsza, 2019). The competition was attended by 93 boys and 20 girls from the State Junior High School in Dubno, Orthodox Theological Seminary in Kremenets, Local Government Junior High School in Kremenets, High School, the School of Economics, Junior High School and Agricultural School of Kremenets Lyceum. They competed in track-and-field events and sports games. The best athlete of the competition was Kowalewski (Dubno), who won the $100 \mathrm{~m}$ race, long jump and high jump. In the competition of sports games, the schoolchildren from the Junior High School of Kremenets Lyceum won the girls' and boys' volleyball competition. Basketball competition was won by the youth of the Orthodox Theological Seminary. The Junior High School of Kremenets Lyceum won in the scoring of schools before the State Junior High School in Dubno. The event was well organised and attracted a wide audience.

Kremenets was the centre where the interschool competitions in winter sports were most often held. On February 16, 1936, skiing competitions took place in Kremenets, with the participation of students from Kremenets schools (Życie Krzemienieckie, 1936, No. 2, p. 76; Wołyń, 1936, No. 9, p. 11). The organiser of the event 
was the District Commander of the Military Training (PW) and the local Committee of Physical Education Teachers. The competition began with a parade of students through the streets of Kremenets. Over 100 students participated in the competition, which proved the popularity of winter disciplines in the Kremenets school environment. Crosscountry skiing was organised at various distances depending on age. Students from the School of Economics, Krzemieniec Junior High School and Lyceum and the Agricultural School stood out in the competition.

The ice hockey tournament of school teams and Kremenets Sports Club (KKS) took place in Kremenets in 1938 (Wołyń, 1938, No. 11, p. 8). The first place was taken by the team of hockey players from the State Junior High School in Dubno, who defeated the teams of Kremenets Interschool Sports Club and the Orthodox Theological Seminary. A year later (1939), an ice hockey tournament was held at Kremenets Lyceum ice rink, with the same teams: the State Junior High School in Dubno, KKS (Kremenets Sports Club), the Theological Seminary in Kremenets and the Kremenets High School Sports Club (KS) (Wołyń, 1939, No. 8, p. 6). The tournament was played according to the cup system. Hockey players of the High School Sports Club (KS) won. The match was a promotion of ice hockey among schoolchildren as well as adults.

The biggest school youth event in winter sports were the School Youth Winter Games (Małolepszy, DrozdekMałolepsza, 2019). The competition, held in Kremenets from January 31 to February 2, 1937, and it was attended by 347 students from 24 high schools from the province of Volhynia. The competition programme consisted of the following disciplines: ice hockey, figure skating, skiing and tobogganing. Figure skating involved individual and pair rides; skiing - girls' races over the distances of $4 \mathrm{~km}$ and $6 \mathrm{~km}$, boys' races - over distances of $7 \mathrm{~km}$ and $9 \mathrm{~km}$; tobogganing: $300 \mathrm{~m}$ downhill toboggan ride (Małolepszy, Drozdek-Małolepsza, 2019). The Junior High School of Kremenets Lyceum won in the overall competition scores in the category of boys and girls. Other educational institutions also stood out in the competition: e.g. the State Junior High School from Dubno, the Local Government Junior High School from Kremenets and the State Junior High School from Zdolbuniv. The ice hockey tournament was won by students of the State Measuring and Road School from Kovel, ahead of Kremenets Junior High School and Kovel Junior High School. 8 teams competed in the ice hockey tournament. The sporting level of the competition was quite high.

\section{Sports competition in education at inter-province and national level}

An interesting form of sports competition was the competition between "The Sułkowskis" Junior High School in Rydzyna (the province Poznań) and Kremenets Lyceum. The initiative of conducting inter-school competitions was raised by the management of "The Sułkowskis" Junior High School in Rydzyna (Małolepszy, DrozdekMałolepsza, 2019). It was specified in the competition regulations that the competition would be held annually in both cities for a change. 15-person teams could participate in the competition. Members of the teams had to have the National Sports Badge as evidence of all-embracing physical development. The results of competition in individual sports events were evaluated collectively, adding up the points obtained by the participant in a given section of the competition.

The editors of the Życie Krzemienieckie magazine pointed to the motives of the initiators of sport competition of two school centres:

(...) willingness to instil traditional inter-university competitions in Poland, (...) the desire to establish contact between two organizationally similar borderland school facilities by bringing the youth of the eastern and western borders closer together, and giving them the opportunity to look at the world as different as the western 
provinces of Poland are for the inhabitants of the eastern borderlands and vice versa" (Życie Krzemienieckie, 1935, No. 4, pp. 171-172).

There were six editions of the competition. The first competition took place on May 13-14, 1933 in Kremenets, then the students from Greater Poland won (85:10). The last edition was held in 1938 in Rydzyna. Young people competed in track-and-field competitions, in sports games and shooting with military and small-calibre weapons. In all editions, the students from the Junior High School in Rydzyna won in the overall score (Małolepszy, DrozdekMałolepsza, 2019). After the fifth edition of the competition the editors of Życie Krzemienieckie wrote: „the growing ties of mutual friendship bind both groups of competitors, the atmosphere in which the competition takes place is getting nicer, the fight of players is becoming more and more gallant" (Życie Krzemienieckie, 1937, No. 10-11, p. 234).

Representation of Lutsk (school district) participated in the School Youth Nationwide Sports Competition in Vilnius (Zaborniak, 2013). The first winter nationwide competition was organised on January 12-13, 1935 in Vilnius. The sport competition was attended by students representing 7 districts: Warsaw, Kraków, Lublin, Lviv, Lutsk, Poznań and Vilnius. Young people competed in ice hockey, figure skating and skiing. The team from Lutsk defended the colours of Volhynia in ice hockey competitions. The team consisted of, among others, students from the State Junior High School in Kovel and schools in Rivne (Przegląd Sportowy, 1935, No. 5, p. 5; Wołyń, 1936, No. 10, p. 10). The team from Lutsk defeated the representation of Warsaw, drew with the teams of Poznan and Lviv, lost their match with the team of Kraków. In the overall scoring of the hockey tournament the team from Volhynia won the third place and was recognised as the tournament's greatest revelation.

\section{Summary}

In the years 1921-1939 there was a development of sport in education in the Volhynia province. This process was particularly evident in the second half of the 1920s and in the 1930s. School sport was especially popular in secondary education. Among sports, school children and adolescents practiced mainly track-and-field events, sport games, shooting, water sports and winter sports. School Sports Circles and Clubs were organised at schools. District and Municipal Committees of Physical Education and Military Training played an important role in the development of school sport. Students participated in competitions organised by committees, intended mainly for schoolchildren.

Sport competition developed mainly at the local, district and province levels. In the 1930s, the representation of the Volhynia (Lutsk) school district participated in nationwide competitions. The elite school competition was a sport competition between Kremenets Lyceum and "The Sułkowskis" Junior High School in Rydzyna. Kremenets was the strongest school sport centre in Volhynia. In addition to Kremenets, strong school sports centres in Volhynia include Dubno, Kovel, Lutsk and Rivne.

\section{References}

Archiwum Akt Nowych w Warszawie, Urząd Wojewódzki Wołyński, sygn. 979/83, Sprawozdanie z sytuacji na Wołyniu we wrześniu 1933 i 1934 r. wraz z planem pracy województwa wołyńskiego, p. 43.

Dziennik Urzędowy Kuratorium Okręgu Szkolnego Wołyńskiego (1925). No. 9, pp. 226-227.

Dziennik Urzędowy Kuratorium Okręgu Szkolnego Wołyńskiego (1926). No. 4, p. 114.

Dziennik Urzędowy Kuratorium Okręgu Szkolnego Wołyńskiego (1926). No. 7, pp. 188-189.

Kęsik, J. (2008). Województwo wołyńskie pod rządami Henryka Józewskiego. „Niepodległość i Pamięć”, 27, p. 194. 
Księga pamiątkowa wydana ku uczczeniu pięciolecia Gimnazjum Państwowego im. Juliusza Słowackiego w Kowlu (1926). Kowel: Gimnazjum Państwowe im. J. Słowackiego.

Małolepszy, E., Drozdek-Małolepsza, T., Bakota, D. (2017). Wychowanie fizyczne i sport w Łucku i w powiecie łuckim w latach 1921-1939. Zarys problematyki. Prace Naukowe Akademii im. Jana Długosza w Częstochowie Kultura Fizyczna, XVI, 2, 47-49. DOI: 10.16926/kf.2017.16.14.

Małolepszy, E., Drozdek-Małolepsza, T. (2019). Sport in the county of Kremenets in the light of "Życie Krzemienieckie" magazine (1932-1939). Sport i Turystyka. Środkowoeuropejskie Czasopismo Naukowe, 2 (3), 45, 46-47. DOI: 10.16926/sit.2019.02.22.

Nowak, L. (1996). Wychowanie fizyczne i sport w Państwowym Szkolnictwie Ogólnokształcącym w Polsce w latach 1918-1939. Poznań: Akademia Wychowania Fizycznego im. Eugeniusza Piaseckiego w Poznaniu.

Przegląd Sportowy (1935). 5, p. 5.

Ustawa z dnia 31 lipca 1924 r. zawierająca niektóre postanowienia o organizacji szkolnictwa; Dz.U. 1924, No. 79, item 776, pp. 1212-1213.

Wychowanie Fizyczne (1925). 3-4, 268.

Wychowanie Fizyczne (1926). 4, 255-256.

Wychowanie Fizyczne (1927). 7-8, 211-212.

Wychowanie Fizyczne (1927). 9-10, 257.

Wołyń (1933). 12, 6.

Wołyń (1933). 25, 9.

Wołyń (1935). 27, 9.

Wołyń (1935). 31, 9.

Wołyń (1935). 40, 8.

Wołyń (1935). 42, 8.

Wołyń (1935). 44, 10.

Wołyń (1936). 9, 11.

Wołyń (1936). 10, 10.

Wołyń (1938). 11, 8.

Wołyń (1939). 8, 6.

Zaborniak, S. (2013). Skoki narciarskie w Polsce w latach 1907-1939. Rzeszów-Krosno: Wydawnictwo Państwowej Wyższej Szkoły Zawodowej im. Stanisława Pigonia w Krośnie.

Życie Krzemienieckie (1932). 5, 28-29.

Życie Krzemienieckie (1934). 2, 53-54.

Życie Krzemienieckie (1934). 6, 269-270.

Życie Krzemienieckie (1935). 4, 171-172.

Życie Krzemienieckie (1935). 10, 454.

Życie Krzemienieckie (1936). 2, 76.

Życie Krzemienieckie (1937). 10-11, 231-233.

Cite this anticle aS: Drozdek-Małolepsza, T., Małolepszy, E. (2020). Sports in Schools in the Province of Volhynia in the Years 1921-1939. Central European Journal of Sport Sciences and Medicine, 3 (31), 115-123. DOI: 10.18276/cej.2020.3-10. 